\title{
A new record for the Mycota of Turkey
}

\section{Ant J Bot Mustafa Emre AKÇAY}

Van Yuzuncu Yll University, Science Faculty, Department of Biology, Van, Turkey

*memreakcay@gmail.com

Received : 19.02 .2020

Accepted : 09.03.2020 Türkiye Mikotası için yeni bir kayıt

Abstract: The marasmioid species, Marasmius collinus (Scop.) Singer, belonging to the family Marasmiaceae, is given as new record for the mycobiota of Turkey from Sarıkamış Allahukeber Mountains National Park (Kars/Erzurum). A brief description of the taxon is given together with its photographs related to macro and micromorphologies.

Key words: Marasmius collinus, Marasmiaceae, new record, Sarıkamış Allahukeber Mountains National Park, Turkey

Özet: Marasmiaceae familyasına ait bir marasmioit tür olan Marasmius collinus (Scop.) Singer Sarıkamış Allahuekber Dağları Milli Parkı'ndan (Kars/Erzurum) Türkiye mikobiyotası için yeni kayıt olarak verilmiştir. Taksonun kısa betimlemesi makro ve mikromorfolojisine ait fotoğraflarla birlikte verilmiştir.

Anahtar Kelimeler: Marasmius collinus, Marasmiaceae, yeni kayıt, Sarıkamış Allahuekber Dağları Milli Parkı, Türkiye

Citation: Akçay ME (2020). A new record for the Mycota of Turkey. Anatolian Journal of Botany 4(1): 8-10.

\section{Introduction}

The genus Marasmius Fr. is morphologically characterized by small convex caps, gills on adnate hymenium, usually thin and bare stipes, hyaline and not amyloid spores, and saprotrophic ecology. The most important distinguishing feature is: Marasmius species are tough types which dry-up but later revive when moistened. Several of the species are known to grow in the characteristic «fairy ring» pattern. (Moser, 1983; Knudsen and Vesterholt, 2008; Antonin and Noordeloos, 2010).

Marasmius genus contains about 500 species in the family Marasmiaceae (Agaricales, Agaricomycetes, Basidiomycota) and according to presented checklists and the recent studies in Turkey, 12 species have so far been identified belonging to this genus (Kirk et al., 2008; Sesli and Denchev, 2014; Solak et al., 2015; Uzun et al., Akçay et al., 2018; Bozok et al., 2018; Keleș, 2018a; Keleş, 2018b; Sadullahoğlu and Demirel, 2018; Sesli et al., 2018a; Sesli et al., 2018b; Uzun and Kaya, 2018; Altuntaş et al., 2019; Akçay, 2019; Çağlı et al., 2019; Sesli and Bandini, 2019; Acar et al., 2020).

The present study aims to make a contribution to the mycobiota of Turkey.

\section{Materials and Method}

Specimens were collected from Gürbüzler village of Selim (Kars-Turkey) district at Allahuekber Mountains National Park in 2016. Morphological and ecological chracteristics of the samples were recorded during the field study and they were photographed in their natural habitats. Then, they were taken to the laboratory and microscopic investigations were carried out on them. Microscopic investigation of the samples were done by using a Leica DM500 light microscope mounted with a Leica ICC50 HD camera. Reagents such as $5 \% \mathrm{KOH}$ and Congo red were used investigation media. Identification was performed with the aid of the relevant literature (Moser, 1983; Breitenbach and Kränzlin, 1991; Antonin and Noordeloos, 2010).

\section{Results}

Basidiomycota R.T. Moore

Agaricales Underw.

Marasmiaceae Roze ex Kühner

Marasmius Fr.

Marasmius collinus (Scop.) Singer

Macroscopic features: Pileus, $15-40 \mathrm{~mm}$ broad, first conical, soon convex-applanate, with involute margin, reddish-brown when young and fresh, then ochraceous or yellow-brown, smooth. Flesh, thin, cream or yellowish at margin, almost white at centre of pileus, smell and taste indistinct. Lamellae, moderately crowded, distant, adnate to almost free, white to cream coloured, with irregularly serrate and concolorous edges. Stipe, 25-60 × 3-6 mm, cylindrical, fistulose, straight, slightly broadened at base, smooth, pale beige, cream-coloured, darker at base (Fig. 1a).

Microscopic features: Spores 7-11 × 4-5.5 $\mu \mathrm{m}$, hyaline, ellipsoid, oblong or cylindrical, slightly attenuated at apex (Fig. 1b). Spore print whitish. Basidia 30-40 × 7-8 $\mu \mathrm{m}$, clavate, 4- spored (Fig. 1c). Basidioles 15-40 × 3-9 $\mu \mathrm{m}$, clavate, cylindrical or fusiform (difficult to distinguish between basidia and basidiols under microscope, because the sterigmata are not very prominent and their sizes are close to each other). Cystidia absent.

Specimen examined: Turkey, Kars, Selim district, Southwest of Gürbüzler village, grassy area, $40^{\circ} 27.253^{\prime} \mathrm{N}$, $42^{\circ} 34.097^{\prime} \mathrm{E}, 2077 \mathrm{~m}, 29.05 .2016$, MEA. 956.

\section{Discussions}

Marasmius collinus is very similar to $M$. oreades (Bolton) Fr., and is found in comparable habitats. These two species can be distinguished from each other by the differences listed in the Table 1 (Moser, 1983; Breitenbach and Kränzlin, 1991; Antonin and Noordeloos, 2010; Josserand, 1955). 


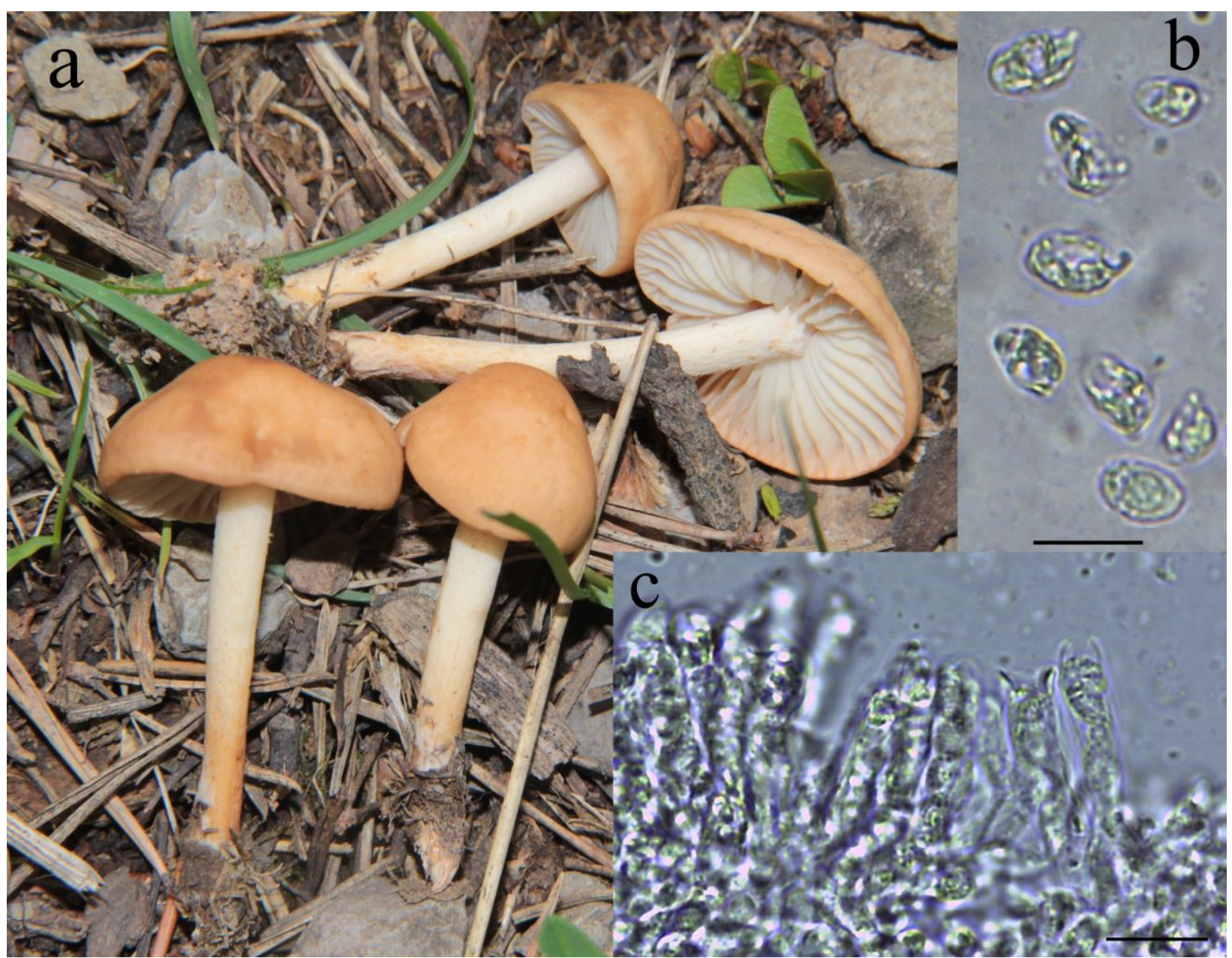

Figure 1. Marasmius collinus: a-basidiomata; b-basidiospores; c-basidia and basidiols (bars= $10 \mu \mathrm{m}$ ).

Table 1. Differences between Marasmius collinus and M. oreades

\begin{tabular}{ccc}
\hline & Marasmius collinus & Marasmius oreades \\
\hline Stipe & $\begin{array}{c}\text { hollow at first, soft } \\
\text { and easily } \\
\text { compressible }\end{array}$ & $\begin{array}{c}\text { stuffed for a long time, } \\
\text { tough }\end{array}$ \\
\hline Spores & $\begin{array}{c}\text { up to } 11 \mu \mathrm{m} \text { in length } \\
\text { and somewhat } \\
\text { narrower }\end{array}$ & $\begin{array}{c}\text { rarely reaches to } 10 \mu \mathrm{m} \\
\text { in length }\end{array}$ \\
\hline Basidia & $30-40 \mu \mathrm{m}$ in length & up to $50 \mu \mathrm{m}$ in length \\
\hline
\end{tabular}

As a result of the study, the number of species belonging to the genus Marasmius has increased from 12 to 13 in Turkey (Sesli and Denchev, 2014; Solak et al., 2015).
It is very important to continue to the macrofungal studies in order to increase the number of determined macrofungi to the expected levels in our country.

Also, in order to benefit sufficiently from edible and medicinal mushrooms and to avoid poisonous mushrooms, they must first be recognized.

\section{Acknowledgments}

The author is thankful to Van Yüzüncü Yıl University Research Fund (BAP Project No. 2012-FBE-D051) for the financial support.

\section{References}

Acar İ, Uzun Y, Akata I (2020). Some macrofungi determined in Şemdinli and Yüksekova districts (Hakkari-Turkey). Kahramanmaraş Sütçü İmam Üniversitesi Tarım ve Doğa Dergisi 23(1): 157-167.

Akçay ME, Uzun Y, Kesici S (2018). Conocybe anthracophila, A new record for the Turkish mycobiota. Anatolian Journal of Botany 2(2): 84-87.

Akçay ME (2019). A new edible macrofungus record for Turkey. Journal of Natural and Applied Sciences of East 2(1): 10-15.

Altuntaş D, Sesli E, Büyük İ, Akata I (2019). Inocybe mytiliodora: A new record for Turkey. Kastamonu Üniversitesi Orman Fakültesi Dergisi 19(3): 284-289.

Antonin V, Noordeloos ME (2010). A nonograph of marasmioid and collybioid fungi in Europe. Eching: IHW-Verlag.

Bozok F, Taşkın H, Büyükalaca S, Doğan HH, Assyov B (2018). Cryptomarasmius corbariensis (Physalacriaceae, Agaricales) in Turkey with first molecular data on the species from Eurasia. Nova Hedwigia 107(1-2): 179-187.

Breitenbach J, Kränzlin F (1991). Fungi of Switzerland,Vol. 3. Lucerne: Verlag Mykologia.

Çağlı G, Öztürk A, Koçak MZ (2019). Two new basidiomycete records for the Mycobiota of Turkey. Anatolian Journal of Botany 3(2): 40-43. 
Josserand, M (1955). Notes critiques sur quelques champignons de la Région Lyonnaise. Bulletin de la Société Mycologique de France 71: 66-125.

Keleş A (2018a). Three new records for Turkish mycobiota. Applied Ecology and Environmental Research 17(1): 983-988.

Keleş A (2018b). New recods of macrofungi from Trabzon Province (Turkey). Applied Ecology and Environmental Research 17(1): 1061-1069.

Kirk PM, Cannon PF, Minter DW, Stalpers JA (2008). Dictionary of the Fungi, 10. edition. Wallingford: CAB International.

Knudsen H, Vesterholt J (2008). Funga Nordica: Agaricoid, Boletoid and Cyphelloid Genera. Copenhagen: Narayana Press.

Moser M (1983). Keys to Agarics and Boleti. Stuttgart: Gustav Fiscer Verlag.

Kaya A (2011). Mantarlar. In: Özuslu E, Tel AZ (eds.). Gaziantep’in Biyolojik Çeşitliliğii. Gaziantep: Doğa Koruma Derneği, pp. 29-60.

Sadullahoğlu C, Demirel K (2018). Flammulina fennae Bas, A new record for Physalacriaceae from Karz Mountain (Bitlis). Anatolian Journal of Botany 2(1): 19-21.

Sesli E, Denchev CM (2014). Checklists of the myxomycetes, larger ascomycetes, and larger basidiomycetes in Turkey. 6th edn. Mycotaxon Checklists Online. (http://www.mycotaxon.com/resources/checklists/sesli-v106-checklist.pdf): 1-136.

Sesli E, Antonín V, Hughes KW (2018a). Marasmiellus istanbulensis (Omphalotaceae), a new species from Belgrade Forest (İstanbul-Turkey). Plant Biosystems 152(4): 666-673.

Sesli E, Antonín V, Contu M, (2018b). A new species of Hygrophorus, H. yadigarii sp. nov. (Hygrophoraceae), with an isolated systematic position within the genus from the Colchic part of Turkey. Turkish Journal of Botany 42(3): 224-232.

Sesli E, Bandini D (2019). Inocybe sphagnophila Bandini \& B. Oertel (Agaricales, Inocybaceae): A new record for the Turkish mycota. Mantar Dergisi 10(1): 44-47.

Solak MH, Işıloğlu M, Kalmış E, Allı H (2015). Macrofungi of Turkey, Checklist, Vol. II. İzmir: Üniversiteliler Ofset.

Uzun Y, Acar İ, Akçay ME, Kaya A (2017). Contributions to the macrofungi of Bingöl, Turkey. Turkish Journal of Botany 41(5): 516-534.

Uzun Y, Kaya A (2018). Marasmiellus vaillantii (Pers.) Singer (Omphalotaceae), a new record for the Turkish mycota. Mantar Dergisi 9(1): 24-27. 